\title{
ECOLOGICAL AND NON-ENVIRONMENTAL CONSTITUTIONAL RESISTANCE OF THE PROTOPLASM OF MARINE ALGAE
}

\author{
By Richard Biebl, Ph.D. \\ Institute for Plant Physiology of the University of Vienna and the \\ Plymouth Laboratory
}

For some years workers on cell physiology have made a practice of investigating the tolerance, or, as perhaps more correctly expressed, the 'resistance', of the protoplasm of plant cells to variations in the environment, both natural and artificial. Weber (I929) and Höfler (1932) have contributed valuable results in their description of the properties of the cytoplasm of plant cells, showing how greatly these may vary among different plants or different cells and tissues of one plant. Experiments have been recorded on the resistance of various plant cells to heat, cold, desiccation, various acids and alkalis, poisons and other chemicals, various radiations, and, for marine algae, to salinity changes in the water.

A closer examination shows that these resistances are not of equal value in the discernment of different types of protoplasms.

Through adaptation to the requirements of the habitat all organisms within a certain biological area show a characteristic resistance to desiccation, exposure to strong light, cold, heat, and other factors. This we shall call the ' ecological resistance'. Although essentially determined by heredity, it varies to a certain extent under external influences.

On the other hand, there is the 'non-environmental constitutional resistance', i.e. the resistance to substances or influences which, under natural conditions, never become so strong that a resistance to them might play an important part in the life of the plant. This includes resistance to acids, alkalis, certain chemicals, X-rays or other short waves. Such differences, often rather obvious, seem to be quite independent of environmental relations; and are particularly suited for characterization of different types of protoplasm or of protoplasmic states. If non-environmental resistance changes during the development of the plant we may interpret it, like changes in the permeability of the cell (Höfler, I937; Hofmeister, I938), as an indirect indication of a change in the general condition of the protoplasm.

\section{ECOLOGICAL RESISTANCE}

Marine algae of various depths from coastal regions show characteristic differences in their resistance to desiccation, temperature, light, $\mathrm{pH}$, and other factors. The plasmolytic behaviour and osmotic resistance of some red 
algae have been previously observed by Höfler (I930, I93I); the resistance to desiccation and other adverse conditions of the habitat by Baker (I909), Johnson \& Skutch (1928) and others; the pH-resistance by Gail (I9I8), Atkins (1922 $a, b)$ and Kylin (1927); and the resistance of marine algae to cold by Kylin (I9I7) and others. An excellent summary of the ecology of marine algae and numerous references are to be found in Fritsch (I945).

The ecological resistances for many marine algae have already been investigated (Biebl, 1937, 1938, 1939 a,b). The variations in resistance to different ecological factors establishes three definite ecological groups: (I) algae from the intertidal zone, (2) algae from low-water level and tidepools, and (3) sublittoral algae.

The osmotic resistance can be found by placing portions of algae in dilute and in concentrated sea water for a period of $24 \mathrm{hr}$. The osmotic value is determined by plasmolysis.

The algae from the intertidal zone show an average resistance to $0 . \mathrm{I}-3.0$ sea water (i.e. I0-300 \% normal sea water), algae from the low-water level and the tide-pools a resistance to $0.4(0.5)-2.0$ sea water, and algae from the sublittoral zone, to only $0.5(0.6)-\mathrm{I} \cdot 5$ sea water. Such ranges in resistance have been observed in algae from Plymouth and also from Heligoland and Naples. Table I shows the osmotic resistance of algae from various levels at Naples.

The same ecological groups were found when examining the resistance to desiccation. The algae were placed, for $\mathrm{I} 3 \mathrm{hr}$., in small, closely sealed jars over a saline solution of varying concentration under atmospheres of relative humidity varying from 83 to I00 \%. Table II shows the results of such experiments with algae from the rocky shores off Heligoland.

In the summer of I95I I made some informative experiments at Plymouth on the influence of direct sunlight on algae from both the intertidal and sublittoral zones.

On 2I September pieces of algae from the intertidal zone and tide-pools, Porphyra umbilicalis (L.) Kütz. f. laciniata (Lightf.) J. Ag., Cladophora utriculosa Kütz., Plumaria elegans (Bonnem.) Schmitz, Callithamnion tetragonum (Wither.) Ag., Griffithsia flosculosa (Ellis) Batt., Phycodrys rubens (Huds.) Batt., Sphondylothamnion multifidum (Huds.) Näg., and from the sublittoral zone, Dictyota dichotoma (Huds.) Lamour., Neomonospora pedicellata (Sm.) G. Feldm. \& Meslin, Polyneura hilliae (Grev.) Kylin and Antithamnion cruciatum (Ag.) Näg., were placed in shallow dishes of white porcelain filled to a depth of $\mathrm{I} \cdot 5 \mathrm{~cm}$. with sea water and exposed to direct sunlight on the roof of the laboratory for 2 hr. from II.30 a.m. to I.30 p.m. G.M.T. The daylight recorder of the laboratory showed that the light received had been 107 kilolux-hours for that time with a maximum vertical illumination of $6 \mathrm{I} \cdot \mathrm{I}$ kilolux and a minimum of 19.9 . At the end of the experiment the water temperature was $17 \cdot 8^{\circ} \mathrm{C}$. 


\section{TABle I. REsistance to DILUTE AND CONCENTRATEd SEA WATER}

Intertidal zone

$$
\begin{aligned}
& \text { Osmotic } \\
& \text { resistance } \\
& \text { (sea water } \\
& \text { concentration) }
\end{aligned}
$$

Cladophora spinulosa $\mathrm{Grev}$

C. bertolonii Kütz.

C. hamosa Kütz.

C. laetevirens Kütz.

Bangia fuscopurpurea (Dillw.) Lyngb.

Porphyra leucosticta Thur.

Polysiphonia pulvinata J. Ag.

Low-water level

Chaetomorpha linum (Mull.) Kütz.

Cladophora utriculosa Kütz.

Ceramium berneri Schffn.

Callithamnion granulatum (Wucluz.) Ag.

Antithamnion cruciatum (Ag.) Näg.

Sublittoral zone

Cladophora prolifera (Roth) Kütz.

C. ramellosa Kütz.

Taonia atomaria (Good. \& Wood.) J. Ag.

Griffithsia furcellata J. Ag.

G. flosculosa (Ellis) Batt. (=setacea)

$G$. schousboei Mont.

Aglaeothamnion scopulorum (Ag.) G. Feldm.

Ceramium diaphanum (Lightf.) Roth var. strictum

(Kütz.) G. Feldm.

Pleonosporium borrerii $(\mathrm{Sm}$.) Näg.

\begin{tabular}{|c|c|}
\hline $0.1-3.0$ & $I \cdot 6$ \\
\hline $0.1-3.0$ & $I \cdot 5$ \\
\hline $0.1-3.0$ & 6 \\
\hline $0.1-2.8$ & \\
\hline $0.1-3.0$ & \\
\hline $0.1-3.0$ & \\
\hline $0.2-3.0$ & \\
\hline $0.0-2.4$ & \\
\hline $0 . \mathrm{I}-2.4$ & \\
\hline $0.3-I \cdot 9$ & \\
\hline $0.4-2.6$ & \\
\hline $0.4-I \cdot 9$ & \\
\hline
\end{tabular}

Plocamium coccineum (Huds.) Lyngb.

Nitophyllum punctatum (Stackh.) Grev.

Acrosorium uncinatum (Turn.) Kylin
$0 \cdot \mathrm{I}-2 \cdot 0$

$0.5-\mathrm{I} \cdot 7$

$0.8-I \cdot 5$

$0.7-I \cdot 4$

$0.6-\mathrm{I} \cdot 5$

$0.6-\mathrm{I} \cdot 4$

$0.6-\mathrm{I} \cdot 5$

$0 \cdot 4-I \cdot 4$

Osmotic

value

(sea water

concentration)

$0.7-\mathrm{I} \cdot 5$

$0 \cdot 7-I \cdot 4$

$0.7-I \cdot 4$

$0 \cdot 6-I \cdot 5$

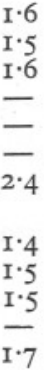

\section{Table II. Resistance to Desiccation}

Algae exposed to air of the stated percentage humidity for $13 \mathrm{hr}$. The figures show the minimum humidity tolerated.

Intertidal zone

Humidity

$(\%)$

Porphyra umbilicalis (L.) Kütz. f. laciniata

(Lightf.) J. Ag.

Rhodocharton floridulum (Dillw.) Näg.

Ulva lactuca (L.) Le Jol.

Enteromorpha linza (L.) J. Ag.

Cladophora rupestris (L.) Kütz.

C. gracilis (Griff.) Kütz.

83.0

83.0

83.0

$86 \cdot 0$

Low-water level

Polysiphonia nigrescens (Sm.) Grev.

Membranoptera alata (Huds.) Stackh.

Plumaria elegans (Bonnem.) Schmitz

Dictyota dichotoma (Huds.) Lamour.

86.0

$94 \cdot 6$

$94 \cdot 6$

94.6

Sublittoral zone

Plocamium coccineum (Huds.) Lyngb.

Antithamnion plumula (Ellis) Thur.

Trailliella intricata Batt.

Halarachnion ligulatum (Woodw.) Kütz. 
The sublittoral algae were killed completely by the irradiation; the algae from the intertidal zone and tide-pools, however, showed little or no injury. Among the algae from the tide-pools only Sphondylothamnion multifidum and Phycodrys rubens, which grow in especially shaded places, were killed.

Under light of injurious intensity the necrotic cells of the red algae first changed to a raspberry red but quickly bleached entirely under more extensive light exposure in contrast to other lethal injuries.

If continuously exposed to two lamps of $350 \mathrm{~W}$. each at a distance of $3 \mathrm{I} \mathrm{cm}$. the difference in the reaction of the intertidal algae and the sublittoral algae can be readily seen after 5 days. After such a long exposure some of the algae from the intertidal zone-Ulva lactuca (L.) Le Jol., Cladophora utriculosa Kütz., Ceramium ciliatum (Ellis) Ducluz, Callithamnion tetragonum (Wither.) Ag., Plumaria elegans (Bonnem.) Schmitz and Polysiphonia furcellata (Ag.) Harv.-were bleached intensively but were still living, as shown by staining with neutral red, while the sublittoral algae and the algae from shady tide-pools-Acrosorium uncinatum (Turn.) Kylin, Dictyota dichotoma (Huds.) Lamour., Heterosiphonia plumosa (Ellis) Batt., Bonnemaisonia asparagoides (Woodw.) Ag. and Neomonospora pedicellata (Sm.) Feldm. \& Meslin-were killed.

The resistance of the protoplasm to light of high intensity therefore also shows the typical characteristics of an 'ecological resistance'.

\section{Non-EnVironmental Constitutional Resistance}

Experiments made in recent years have shown that the resistance of the cells of various plants to minute quantities of various elements, such as boron, zinc, manganese and vanadium, differs widely (Biebl, 1947, I949, I950). If moss leaves or slices from the epidermis of phanerogams are brought into graded solutions of salts of the above substances we find that the death-point of the various plants differs rather widely.

Such experiments were made with a series of solutions, of boric acid $\left(\mathrm{H}_{3} \mathrm{BO}_{3}\right)$, manganese sulphate $\left(\mathrm{MnSO}_{4}\right)$, zinc sulphate $\left(\mathrm{ZnSO}_{4}\right)$, and vanadium sulphate $\left(\mathrm{VOSO}_{4}\right)$, of concentrations $3, \mathrm{I}, 0 . \mathrm{I}, 0.0 \mathrm{I}, 0.00 \mathrm{I}$, and $0.000 \mathrm{I} \%$. The material was immersed and examined $48 \mathrm{hr}$. later. Table III, giving the results, shows the resistance of the epidermal cells of some dicotyledons and the leaflets of some mosses and liverworts to the solutions mentioned. Sulphates were chosen for the experiment, since the sulphate radicle is known to be least harmful to protoplasm.

The picture which emerges shows not that some plants are very sensitive to all these substances while others are resistant, but rather that a given plant may be relatively resistant to one substance and relatively sensitive to another. Therefore, each separate 'combination of resistances' can be used as a differentiating characteristic for the various kinds of protoplasm. 
Table III shows that the resistance of the phanerogams to boron, zinc and vanadium is relatively small and varies but little, while the resistance to manganese differs widely.

On comparing the resistance limits of those phanerogams with that of some mosses and liverworts we find that the latter behave quite differently. Some mosses can stand $\mathrm{H}_{3} \mathrm{BO}_{3}$ or $\mathrm{ZnSO}_{4}$ in solutions of as much as $3 \%$, and the death-point in $\mathrm{MnSO}_{4}$ lies generally above $20 \%$ and in $\mathrm{VOSO}_{4}$ at 5-10 \%.

Among the marine algae it was interesting, on the one hand, to find out whether the chemical resistance of the protoplasm holds a similar exceptional position like that of the mosses when compared with phanerogams. On the other hand, the marine algae are excellent objects for deciding experimentally whether there is any relationship between 'non-environmental' chemical resistance and 'ecological' resistance.

Table III. Resistance to Boron, Zinc, Manganese and Vanadium of SOME Dicotyledons (EPidermal Cells) ANd Mosses (LeAflets)

The tissues were in each case exposed to the following strengths of solution: $3, \mathrm{I}, \mathrm{O} . \mathrm{I}, \mathrm{O}$.0 I $0.00 \mathrm{I}$, and $0.000 \mathrm{I} \%$. The strengths given are of the strongest solution which the tissues resisted.

Beta vulgaris (mangel-wurzel)
Beta vulgaris (beet-root)
Brassica oleracea (kohlrabi)
Brassica oleracea (cabbage)
Raphanus sativus
Solanum tuberosum
Daucus carota
Pisum sativum
Phaseolus multiflorus
Mnium punctatum
M. rostratum
Bazzania trilobata
Plagiochila asplenioides

\begin{tabular}{|c|c|c|c|}
\hline $\mathrm{H}_{3} \mathrm{BO}_{3}$ & $\mathrm{ZnSO}_{4}$ & $\mathrm{MnSO}_{4}$ & $\mathrm{VOSO}_{4}$ \\
\hline $\begin{array}{l}0.1 \\
0.1\end{array}$ & $\begin{array}{l}0.01 \\
0.01\end{array}$ & $\begin{array}{l}3.0 \\
3.0\end{array}$ & $\begin{array}{l}0.01 \\
0.00 I\end{array}$ \\
\hline 0.1 & 0.001 & 0.001 & 0.001 \\
\hline 0.1 & 0.001 & 0.001 & 0.001 \\
\hline I.O & 0.001 & 0.001 & 0.001 \\
\hline 0.1 & 0.001 & $3 \cdot 0$ & 0.0001 \\
\hline 0.1 & 0.001 & 0.01 & 0.001 \\
\hline$O \cdot I$ & \pm 0.001 & $O \cdot I$ & 一 \\
\hline$O \cdot I$ & 0.001 & 0.001 & 一 \\
\hline 3.0 & 0.1 & 3.0 & 3.0 \\
\hline O.I & 0.001 & 3.0 & 3.0 \\
\hline $0 . I$ & 3.0 & 3.0 & $3 \cdot 0$ \\
\hline 3.0 & 0.1 & 3.0 & 3.0 \\
\hline
\end{tabular}

Algae from the intertidal zone, from tide-pools and from the low-water level on the rocky shore at Wembury (east of Plymouth), and sublittoral algae collected at Plymouth (mostly near the Mewstone) were placed in seawater solutions of $\mathrm{H}_{3} \mathrm{BO}_{3}, \mathrm{ZnSO}_{4}, \mathrm{MnSO}_{4}$ and $\mathrm{VOSO}_{4}$ and examined $48 \mathrm{hr}$. later.

All four substances are soluble in sea water, but the $3 \%$ solutions of $\mathrm{ZnSO}_{4}$ and $\mathrm{MnSO}_{4}$ show a slight deposit at the bottom of the bottle. The experiments were made with algae which, owing to the size of their cells, were especially suited for microscopic examination.

Death in almost all the green and the red algae was accompanied by a strong swelling of the membranes. This was most prominent in Callithamnion tetragonum when placed in lethal solutions of boron and vanadium, and less so if placed in $\mathrm{ZnSO}_{4}$ and $\mathrm{MnSO}_{4}$. Moreover, in the species of Cladophora the complex chloroplasts within the dead cells were destroyed and 
frequently decomposed into lumps of a dark green colour. This destruction of the normal structure of these algae was especially obvious when they were placed in strong solutions of manganese. The majority of red algae change to a red-violet colour when dead. This and the white colour of the swollen membranes, even of the small cells of Plumaria elegans, made dead tissues easily recognizable. In death the plastids of most red algae are displaced, rounded off, or occasionally stuck together. In this way also the dead cells of Dictyota dichotoma can be distinguished from the living. In this alga the living, homogeneously coloured plastids are, as a rule, distributed close to the cell wall in the cytoplasm; in the dead cell they are displaced, stick together, and have a dark contour.

Especially difficult to recognize are the dead cells of Ulva lactuca, but staining with neutral red helps (6 drops of a I \% solution of neutral red in distilled water to 50 c.c. of sea water). The living cells show red vacuoles, while the dead cells remain colourless. The same is true of Porphyra, but the cell sap of the living cells is not stained homogeneously and one can see dark red globules in the protoplasm. Similar globules are also to be found in the vacuoles after neutral red staining in Callithamnion tetragonum and in the species of Polysiphonia. On the other hand, Ceramium ciliatum shows a homogeneous red colour of the cell sap. But if a subsequent plasmolysis is made small red globules appear. This biological reaction of Ceramium ciliatum was of especial value for experiments in the resistance to light as described earlier in this paper, where the first injury from light was a strong bleaching of the plastids so that it was often only possible to recognize the cells as living through vital staining with neutral red. The neutral red staining of the living cells of Dictyota is characterized by a granulated deposit. Neomonospora and other red algae, on the other hand, show a diffused red staining of the cell sap. In the species of Cladophora plasmolysis in sea water of double or treble concentration is a good test for living cells.

The results of experiments on the resistance of some algae from various habitats to boron, zinc, manganese and vanadium are given in Table IV.

Table IV gives a clear answer to our two initial questions. (I) The resistance limits and the combination of the resistances against the chemicals used are similar to those of the phanerogams. The difference in resistance to boron, zinc, manganese, and vanadium between phanerogams and marine algae is far smaller than that between phanerogams and mosses. (2) There is no relationship between the ecological resistance of marine algae to sea water of various concentration, to desiccation or light exposure, on the one hand, and the chemical resistance to boron, zinc, manganese and vanadium, on the other. It differs within an ecological group, but is typical for the species.

In the above experiments the survival of the protoplasts offered an indication of the resistance of the cell. The death of the protoplasts indicates that the resistance limit has been exceeded, and this allows a sharp definition of 
the range of resistance. The fact that injurious influences which are not quite lethal affect the physiological processes within the cells can also be observed occasionally by cytological methods through changes in the protoplasm viscosity, and through permeability or the effects of vital staining. But the examination of the internal conditions of the cell under the stress of extremely strong but not quite lethal conditions is another question. It can be better answered by examining the progress of certain physiological processes such as respiration or assimilation (Montfort, I936, I937; Montfort \& Hahn, I950; Stocker \& Holdheide, I937).

\section{Table IV. Resistance to Boron, Zinc, Manganese and Vanadium of Algae FROM VARIOUS Habitats}

The algae were placed in solutions of the same strength as in Table III, the strongest solution which they survived being recorded. Figures in brackets show that the alga was partially killed. At concentrations lower than this the tissues survived.

\begin{tabular}{|c|c|c|c|c|}
\hline \multicolumn{5}{|c|}{ Intertidal zone } \\
\hline Cladophora ramosissima (Drap.) Kütz. & $(I \cdot O)$ & $(0 \cdot I)$ & 0.1 & 0.01 \\
\hline C. rupestris (L.) Kütz. & I.O & 0.1 & 3.0 & 0.01 \\
\hline Ulva lactuca (L.) Le Jol. & O.I & 0.01 & $(I \cdot O)$ & 0.01 \\
\hline Ceramium ciliatum (Ellis) Ducluz & 0.1 & 0.01 & $(3, I)$ & 0.01 \\
\hline \multicolumn{5}{|c|}{ Low-water level and Tidepools } \\
\hline C. utriculosa Kütz. & $\mathrm{I} \cdot \mathrm{O}$ & $(0.1)$ & $(0 \cdot \mathrm{I})$ & 0.01 \\
\hline Plumaria elegans (Bonnem.) Schmitz & $0 \cdot 1$ & $(\mathrm{I}, 0 . \mathrm{I})$ & $3 \cdot 0$ & $(0.01)$ \\
\hline Callithamnion tetragonum (Wither.) C.Ag. & 0.01 & $(\mathrm{I} \cdot 0)$ & $(\mathrm{I} \cdot 0)$ & $(0.01)$ \\
\hline Polysiphonia elongella Harv. & $(I \cdot 0)$ & $(0 \cdot I)$ & $\mathrm{I} \cdot \mathrm{O}$ & 0.001 \\
\hline Polysiphonia sp. & 0.1 & 0.1 & $i \cdot 0$ & 0.001 \\
\hline P. furcellata (Ag.) Harv. & & $(0.1)$ & $(I \cdot 0)$ & 0.01 \\
\hline \multicolumn{4}{|c|}{ Sublittoral zone } & \\
\hline Dictyota dichotoma (Huds.) Lamour. & O.or & 0.1 & $I \cdot 0$ & $(0.01)$ \\
\hline Dictyopteris membranacea (Stackh.) Batt. & 0.01 & 0.01 & $3 \cdot 0$ & $(0.0001)$ \\
\hline Antithamnion cruciatum (Ag.) Näg. & $0 \cdot \mathrm{I}$ & $O \cdot I$ & $O \cdot I$ & (0.0I) \\
\hline Heterosiphonia plumosa (Ellis) Batt. & $\mathrm{I} \cdot \mathrm{O}$ & $(0.1)$ & $(3 \cdot 0)$ & $(0.01)$ \\
\hline $\begin{array}{l}\text { Neomonospora pedicellata (Sm.) G. Feldm. } \\
\text { \& Meslin }\end{array}$ & $0 . \mathrm{I}$ & $(0 \cdot I)$ & $(3 \cdot 0)$ & 0.001 \\
\hline
\end{tabular}

I am sincerely grateful to the Director, Mr F. S. Russell, F.R.S., and to Dr W. R. G. Atkins, F.R.S., Head of the Physiological Department, for my kind reception at the Marine Biological Laboratory at Plymouth and for all the facilities provided.

\section{SUMMARY}

Marine algae supply good examples of the difference between 'ecological' and 'non-environmental constitutional' resistance of the protoplasm of their cells to variations in the environment. The resistance to ecological factors such as diluted or concentrated sea water, to desiccation, or to light exposure is very similar among algae occupying the same habitat. On the basis of the 
degree of resistance shown, three ecological groups can be distinguished: (I) algae from the intertidal zone; (2) algae from the low-water level and tidepools; and (3) sublittoral algae.

On the other hand, there is no similarity in the resistance to chemical substances $\left(\mathrm{H}_{3} \mathrm{BO}_{3}, \mathrm{ZnSO}_{4}, \mathrm{MnSO}_{4}, \mathrm{VOSO}_{4}\right)$ of algae within a given ecological group. It is characteristic for a given species.

\section{REFERENCES}

Atkins, W. R. G., I922a. The hydrogen ion concentration of the cells of some marine algae. Fourn. Mar. Biol. Assoc., Vol. I2, pp. 875-8.

- $1922 b$. The influence upon algal cells of an alteration in the hydrogen ion concentration of sea water. Fourn. Mar. Biol. Assoc., Vol. I2, pp. 789-9I.

BAKER, S. M., I909. On the causes of the zoning of brown seaweeds on the seashore. New Phytologist, Vol. 8, pp. I96-202.

BIEBL, R., 1937. Oekologische und zellphysiologische Studien an Rotalgen der englischen Südküste. Beih. z. Bot. Zentralbl., Bd. 57, Abt. A, pp. 38I-424.

- 1938. Trockenresistenz und osmotische Empfindlichkeit der Meeresalgen verschieden tiefer Standorte. Fahrb. f. wiss. Bot., Bd. 86, p. 350.

- I939a. Ueber die Temperaturresistenz von Meeresalgen verschiedener Klimazonen und verschieden tiefer Standorte. Fahrb. f. wiss. Bot., Bd. 88, pp. 389-420.

— 1939b. Protoplasmatische Oekologie der Meeresalgen. Ber. d. Deutsch. Bot. Ges., Bd. 57, pp. (78)-(90).

_ 1947. Die Resistenz gegen Zink, Bor und Mangan als Mittel zur Kennzeichnung verschiedener pflanzlicher Plasmasorten. Sitz. Ber. d. Akad. d. Wiss. Wien, Math. nat. Kl., Abt. I, Bd. I55, pp. I45-I57.

- 1949. Vergleichende chemische Resistenzstudien an pflanzlichen Plasmen. Protoplasma, Bd. 39, pp. I-13.

- 1950. Ueber die Resistenz pflanzlicher Plasmen gegen Vanadium. Protoplasma, Bd. 39 , pp. 25 I-9.

FrITSCH, F. E., I945. The Structure and Reproduction of the Algae. Vol. II. 939 pp. Cambridge.

GaIl, F. W., I918. Some experiments with Fucus to determine the factors controlling its vertical distribution. Publ. Puget Sound Biol. Sta., Vol. 2, pp. I39-5I.

HöfleR, K., I930. Das Plasmolyse Verhalten der Rotalgen. Zeitschr. f. Bot., Bd. 23, pp. $570-88$.

— I93I. Hypotonietod und osmotische Resistenz einiger Rotalgen. Oest. Bot. Zeitschr., Bd. 80, pp. 5I-7I.

- I932. Vergleichende Protoplasmatik. Ber. d. Deutsch. Bot. Ges., Bd. 50, pp. (53)-(67).

- - I937. Spezifische Permeabilitätsreihen verschiedener Zellsorten derselben Pflanze. Ber. d. Deutsch. Bot. Ges., Bd. 55, pp. (133)-(I48).

Hofmeister, L., I938. Verschiedene Permeabilitätsreihen bei einer und derselben Zellsorte von Ranunculus repens. Fahrb. f. wiss. Bot., Bd. 86, pp. 40I-I9.

Johnson, D. S. \& SkuTCH, A. F. I928. Littoral vegetation on a headland of Mt. Desert Island, Maine. I and II. Ecology, Vol. 9, pp. I88-215; 307-38.

KyLIN, H., I9I7. Ueber die Kälteresistenz der Meeresalgen. Ber.d.Deutsch. Bot. Ges., Bd. 35 , pp. $370-84$.

- 1927. Ueber den Einfluss der Wasserstoffionenkonzentration auf einige Meeresalgen. Botaniska Notiser, Lund, p. 243. 
MONTFort, C., I936. Umwelt, Erbgut und physiologische Gestalt. I. Lichttod und Starklichtresistenz usw. Fahrb. f. wiss. Bot., Bd. 84, pp. I-57.

- 1937. Die Trockenresistenz der Gezeitenpflanzen und die Frage der Uebereinstimmung von Standort und Vegetation. Ber. d. Deutsch. Bot. Ges., Bd. 55, pp. (85)-(95).

MonTfort, C. \& HaHN, H., I950. Atmung und Assimilation als dynamische Kennzeichen abgestufter Trockenresistenz bei Farnen und höheren Pflanzen. Planta, Bd. 38, pp. 503-15.

StOCKER, O. \& HoldHEIDE, W., I937. Die Assimilation Helgoländer Gezeitenalgen während der Ebbezeit. Zeitschr. f. Bot., Bd. 32, pp. I-59.

Weber, F. I929. Protoplasmatische Pflanzenanatomie. Protoplasma, Bd. 8, pp. 29I306. 